\title{
A NEW ADVANCE OF THE JAN MAYEN GLACIERS AND A REMARKABLE INCREASE OF PRECIPITATION
}

\author{
By H. Н. Lамв \\ (Meteorological Office, Bracknell, Berkshire, England) \\ J. R. Probert-Jones \\ (Department of Meteorology, Imperial College, London) \\ and J. W. SheArd \\ (Department of Botany, Imperial College, London)
}

\begin{abstract}
A new advance since about 1954 of the glaciers descending on all sides of the great volcanic mountain Beerenberg $\left(2,277 \mathrm{~m}\right.$.) on the island of Jan Mayen (lat. $71^{\circ} \mathrm{N}$., long. $8^{\circ} \mathrm{W}$.) has been reported. Annual precipitation in the area appears to have risen fairly steadily and in the I950's had almost doubled as compared with the I920's. Other places around the Greenland Sea show substantial increases of precipitation after 1920 as compared with the 1910-20 rate, but mostly attained a maximum in the 1930 's or around 1940. Periodicities are briefly discussed as well as secular change. Temperatures at Jan Mayen have fallen somewhat since the 1930's but they have not altered much since the 1940's. The likely causes in terms of changes of the atmospheric circulation and other circumstances, including lag in the glaciers' response, are briefly discussed. The increase of precipitation seems to be the main, almost the sole, causative factor in the glacial advance.
\end{abstract}

RÉsumé. Depuis environ 1954 on a signalé une nouvelle avance des glaciers descendant sur toutes les faces de la grande montagne volcanique Beerenberg $(2277 \mathrm{~m})$ sur l'île de Jan Mayen (lat. $7 \mathrm{I}^{\circ} \mathrm{N} ; \mathrm{l}^{\circ} \mathrm{long}$. $\left.8^{\circ} \mathrm{W}\right)$. Les précipitations annuelles dans cette zone semblent avoir augmenté d'une façon relativement stable et ont presque doublé dans les cinquantes par rapport à celles des vingts. D'autres endroits autour de la Mer du Groënland montrent des accroissements notables des précipitations après 1920 en comparaison avec les valeurs de 1910-20, mais le plus souvent elles ont atteint un maximum dans les trentes ou autour de r940. Les périodicités sont brièvement discutées aussi bien que le changement séculaire. Les températures à Jan Mayen ont baissé quelque peu à partir des trentes mais elles n'ont pas changé beaucoup depuis 1940 . On discute brièvement les causes probables en fonction des changements de la circulation atmosphérique et d'autres possibilités comprenant le déphasage dans la réponse des glaciers. L'accroissement des précipitations semble être le principal, presque le seul, facteur causal de l'avance glaciaire.

Zusammenfassung. Es liegen Berichte über einen neuen Vorstoss, seit etwa 1954 vor, der Gletscher, die allseits von dem grossen Vulkan Beerenberg $(2277 \mathrm{~m})$ auf Jan Mayen $\left(7 \mathrm{I}^{\circ} \mathrm{N}\right.$ geogr. Breite; $8^{\circ} \mathrm{W}$ geogr. Länge) abfliessen. Der jährliche Niederschlag in diesem Gebiet scheint annähernd stetig angestigen zu sein und hat sich in den 5oer-Jahren gegenüber den 2oer-Jahren beinahe verdoppelt. Andere Orte um die Grönland-See zeigen wesentliche Zunahme des Niederschlages nach 1920 gegenüber den Mengen von I9 IO-20, erreichten aber ihr Maximum meist in den 3oer-Jahren oder um 1940. Periodizitäten und säkulare Schwankungen werden kurz diskutiert. Die Temperaturen auf Jan Mayen sind seit den 3oer-Jahren etwas gefallen, haben sich aber seit den 4 oer-Jahren nicht wesentlich geändert. Zur Erklärung werden Änderungen in der atmosphärischen Zirkulation herangezogen; andere Gegebenheiten, wie die Verzögerung in der Reaktion der Gletscher, werden kurz diskutiert. Die Zunahme des Niederschlages scheint die wichtigste, wenn nicht überhaupt die einzige, Ursache für den Gletschervorstoss zu sein.

\section{State of the Jan Mayen Glaciers}

The I959 and I96r University of London Jan Mayen and Beerenberg Expeditions have reported a new advance of most of the island's glaciers, estimated to date from about I954 and to have accelerated since i959. Measurements were concentrated on the southern glacier,

\section{Table I. Variations of Sørbreen, Jan Mayen}

Year

1817

$1876-77$

1882-83

1938

1945

1949

I 959

1961
Observation source

William Scoresby, $j r$.

Norwegian North Atlantic Expedition

Austrian Polar Year Expedition

Imperial College Expedition

Aerial photograph

Norwegian Survey (map published 1959)

University of London Jan Mayen Expedition

University of London Beerenberg Expedition

\section{Horizontal distance of snout from the sea}

$\mathrm{m}$.

Discharging into the sea

Snout just reaching the sea

80 (approx.)
930
1130
1210
1063
939


Sørbreen, which has its origin in the ice fields on the upper part of the mountain outside the crater. This is the most accessible of the Jan Mayen glaciers and has been most frequently reported on in the past. Previous observations are summarized in Table I.

Eruptions of the volcano may have disturbed the glaciers a century and more ago, and must be considered if only to dismiss them as regards any significant interference with the response of the glaciers to the changing climate. The island is elongated in a north-east to south-west direction, the volcano Beerenberg (2,277 m.) occupying the north-eastern end and being $15 \mathrm{~km}$. broad at sea-level; a low-lying neck in the middle of the island joins this mountain to another piece of mountainous terrain forming the south-western end of Jan Mayen, which is almost $60 \mathrm{~km}$. long. The isthmus, on or near which the weather station has always been situated since it began in $192 \mathrm{I}$, has been built up materially by lava flows since the island was first known in the early seventeenth century, and a small off-lying isle has become joined on at this point. Eruptions were observed in 1732 (only fire and ash for 28 hours), 1746 and 18 I 8 . Continued activity was indicated by steam issuing from the south-western end in $188_{2}-83$, though abnormal heat flow at this point would not affect the glaciers. The eruption in 1818 may have melted some of the ice observed by Scoresby the year before, but it was not a great

(a)

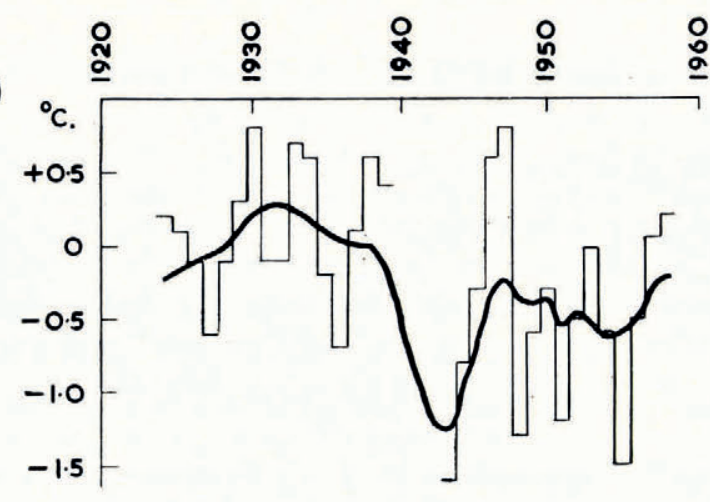

(b)

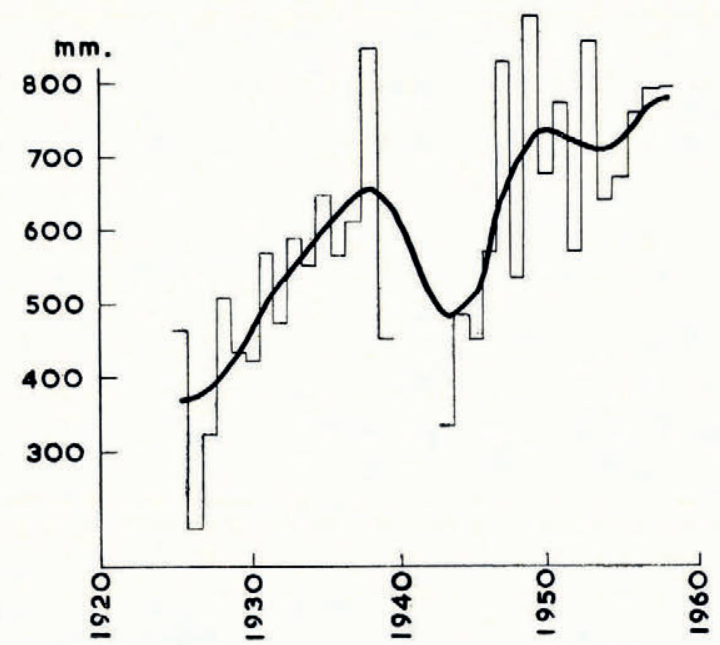

Fig. I. Trends at Jan Mayen. (a) Temperature. (b) Precipitation. Bold curves, smoothed. Narrow line indicates yearly values 
eruption and from the position of the erupting point any effect on the glaciers was probably negligible.

Scoresby revisited the island in 1834 , but no noteworthy change in the glaciers seems to have been reported; the lack of sea ice anywhere in the vicinity in that year was the remarkable feature. The island was visited again in July 1856 by Lord Dufferin who found it heavily beset by the sea ice: from his difficulty in getting ashore at any point-his first approach was evidently opposite Sørbreen though he tried all the eastern and northern sides-and his account of "seven enormous glaciers roll[-ing] down into the sea" it appears that the ice cover on Beerenberg was probably greater than either in 1817 or 1876 . Lord Dufferin's is the only known observation from this period which probably contained the climax of the glaciation.

Retreat of the glacier snouts had certainly begun by 1882 , a time when some deficiency of precipitation is more likely to have been responsible than change of temperature, since it was a cold epoch with much sea ice. After 1882 there was a great retreat, in which rising temperatures must ultimately have played some part. This was followed by some advance in the cold decade r9io-rg to a stand around I920 which has left ice-cored moraines (though some of these are being absorbed by the now advancing ice). The advance to the r 920 stand may be associated partly with increased precipitation in the decade of vigorous atmospheric circulation and cyclonic activity about fifteen years earlier-cf. the precipitation curves for Bodø and Teigarhorn in Figure 3 and the circulation maps for $1900-09$ in Lamb and Johnson (1959, I96r). By $193^{8}$ (Jennings, I948) the glaciers were in rapid retreat and this continued through (or after) the cold years 1 $94^{0}-42$. There was a few months' interruption of weather observations on Jan Mayen in $1940-42$, occasioned by the war. It can, however, be accepted that these years of the great European winters were particularly cold years at Jan Mayen and probably elsewhere in the Norwegian sector of the Arctic (Hesselberg and Johannessen, 1958). There was also a change of observing site $5^{-6} \mathrm{~km}$. across to the north-west shore of the isthmus, which appears unimportant in relation to the scale of the mountain to the north-east of both sites and the magnitude of the trend towards greater precipitation.

The 196I observations showed features characteristic of an advancing glacier. The snout had not only advanced but had thickened and the terminal ice wall had increased in height. The breadth of the glacier had also increased. Surface flow rates measured by lines of stakes set up across the glacier at altitudes about 100,300 and $900 \mathrm{~m}$. increased with height (being respectively $4 \cdot 6,6 \cdot 9$ and $32 \cdot 8 \mathrm{~cm}$./day over the summer season mid-June to mid-August).

\section{Temperature and Pregipitation at Jan Mayen}

In Figure $\mathrm{I}$ the yearly average surface temperature and total precipitation figures for Jan Mayen have been smoothed by a [4-] [4] smoothing function, namely the operator

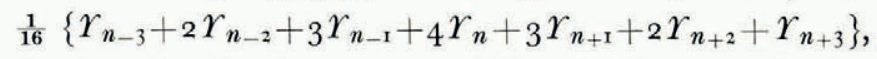

where $Y_{n}$ stands for the value for the year $n$ and $r_{n-1}$ for the value for the year before $n$ and so on. Values for the individual years are shown by a narrow line. In this the change of site of the observing station during the war has been ignored on the grounds that there was no semblance of effects likely to be attributable to it, nor was the change such that for topographical reasons any obvious effects (except perhaps on winds from the north-east) would be expected. In the period I94 I to I 948 there were several further slight changes of site believed trivial in relation to the magnitudes of the trends appearing in the Jan Mayen temperature and precipitation series. Values are plotted against year $n$ in Figure $\mathrm{r}$.

The trend of annual mean surface temperature at Jan Mayen since the 1920 's is in close agreement with the trend of indices of the vigour of the general atmospheric circulation over the North Atlantic (Lamb and Johnson, 1959, I96I). It is to be expected that epochs of maximum vigour of the atmospheric circulation should coincide with least cold conditions in the Arctic, owing to the increased exchange with other latitudes. Maximum strength of the 
surface winds in and around Greenland, Spitsbergen and the seas north of Iceland around 1930-38, followed by less frequent gales there since and increasing windiness south of Iceland, is also apparent from the wind observations at land stations and from ships at sea (Lamb, 1957). It is also known that the sea ice was being driven out of the central Arctic in the r930's and melting off east Greenland at rates unmatched before or since in the years of which we have any adequate record.

There was no further fall of temperature at Jan Mayen from the r940's to the I950's, the two decade means being inappreciably different from each other. In this, however, Jan Mayen appears as a somewhat localized exception to a general cooling of the Arctic surface temperatures by ${ }^{\circ} \mathrm{C}$. or rather more from the 1940's to I950's (Mitchell, I961, in press), which has produced symptoms of a modest increase of the sea ice-cf. figures for overall area of the ice and its incidence at the coast of Iceland given by Lamb and Johnson (1959, p. I 24).

The net fall of annual mean surface temperature at Jan Mayen from $+0.06^{\circ} \mathrm{C}$. in the warmest decade $1927-36$ to $-0.35^{\circ} \mathrm{C}$. in the latest decade $195^{2-6} \mathrm{I}$, though slight, is

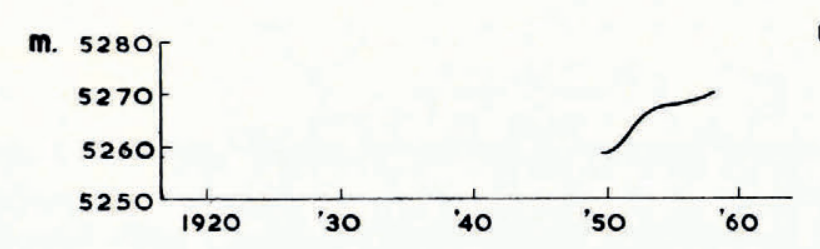

1000-500mb.

Thickness

(smoothed)
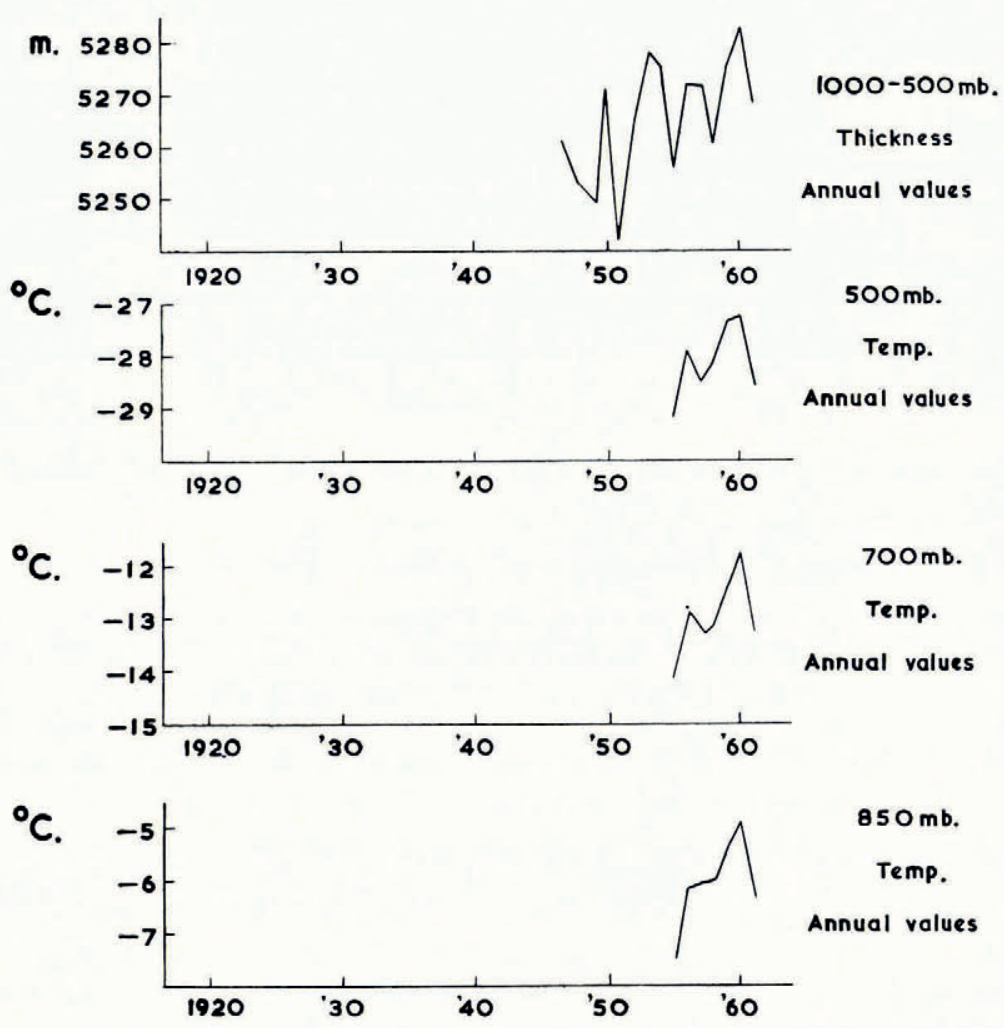

Fig. 2. Upper air temperature and thickness (height difference) of the 1,000-500 millibar layer over Jan Mayen, annual mean values 
statistically significant at about the 3 per cent level (Student's $t$-test). I955 was decidedly colder than any year in the warmest decade and 1952, I954 and I959 were all comparable with the two coldest years of the time around 1930.

Changes of upper air temperature over Jan Mayen are examined in Figure 2. Actual annual mean temperatures observed over Jan Mayen at the 850 , 700 and $500 \mathrm{mb}$. levels are only shown from 1955, taken from Monthly Climatic Data for the World (U.S. Weather Bureau). I, Ooo-500 mb. thickness values can, however, be carried back to 1947 (top two curves in Figure 2) by interpolation from the isopleths drawn on the charts of the British and German weather services, based upon the network of radio-sonde ascents in Greenland, Iceland and Europe. The topmost curve (Fig. 2) shows the result of a [4-] [4] smoothing of the annual thickness values seen in the graph just below it. A change of $20 \mathrm{~m}$. in I, $000-500 \mathrm{mb}$. thickness corresponds to a $\mathrm{I}^{\circ} \mathrm{C}$. change in the mean temperature of the air column. It must be admitted that the apparent rising trend of upper air temperatures over the years available is small, amounting to something less than a degree Celsius, and cannot be verified as beyond the limits of observational inhomogeneities. Few, if any, trends of upper air temperature over the Arctic have so far been published. This first fragment of evidence, if real, may represent a somewhat local peculiarity of Jan Mayen - as in the case of the surface temperatures which remained steady or slightly rising there from the I940's to the I950's. The evidence is important in the present connection, however, as indicating that the beginnings of advance in the Jan Mayen glaciers, particularly at the higher levels, are unlikely to be attributable to a down-turn of the temperatures prevailing.

From Figure I (b) it does appear that there should be some noticeable results from the great increase of precipitation at Jan Mayen, amounting to nearly roo per cent since the I920's, with possibly some contributory effect attributable to the slight fall of temperature away from the level of 1930 . Both, however, imply a lag of about 15 years in the response of the Sørbre snout to changes of atmospheric conditions, unless we are to attribute a decisive and surely inordinate importance to the individual cold years since 1940-43, viz. I 948 and 1955, both of which were dry by comparison with the recent average (1948 $T_{m}-\mathrm{I} \cdot 2^{\circ} \mathrm{C}$., $R 535 \mathrm{~mm}$.; I955 $T_{m}-\mathrm{I} \cdot 5^{\circ} \mathrm{C}$., $R 672 \mathrm{~mm}$.). The change of precipitation from the earliest decade to the latest appears highly significant in the statistical sense $(0 \cdot \mathrm{I}$ per cent level passed, Student's $t$-test).

\section{Pregipitation Changes at Different Places in this Sector of the Arctic and Sub-Arctic}

The magnitude of the rainfall changes in this region accompanying the better-known changes of temperature and circulation regime in the Arctic does not seem to have come to notice hitherto in the meteorological literature. The percentage changes at several of the stations discussed below exceed the greatest changes known to the authors to have been reported in other parts of the world.

Figure 3 shows the rainfall curves for Jan Mayen (lat. $7 \mathrm{I}^{\circ} \mathrm{N}$., long. $8^{\circ} \mathrm{W}$.) ; Bodø, Norway (lat. $67^{\circ}$ N., long. $14^{\circ}$ E.); Angmagssalik, south-east Greenland (lat. $65.5^{\circ}$ N., long. $37 \cdot 5^{\circ}$ W.) ; Stykkisholm, west Iceland (lat. $65^{\circ}$ N., long. $22 \cdot 5^{\circ} \mathrm{W}$.) ; Teigarhorn, east Iceland (lat. $64.5^{\circ} \mathrm{N}$., long. $14^{\circ}$ W.) and Thorshavn (Højvig), Faeroe Islands (lat. $62^{\circ}$ N., long. $6.5^{\circ}$ W.) - a selection of places around the Norwegian/Greenland Sea and north-eastern Atlantic, taken from World Weather Records and the Danish and Norwegian Year Books, and chosen in the belief that the known changes of site are unlikely in these cases to have produced effects comparable in magnitude with the large trends indicated in the region. Unfortunately no curve covering a sufficiently long period of years can be shown for Spitsbergen or points north of Angmagssalik in east Greenland because of short or broken records and changes of site. All the curves have been smoothed as in Figure $\mathrm{I}$. 
360 JOURNAL OF GLAGIOLOGY
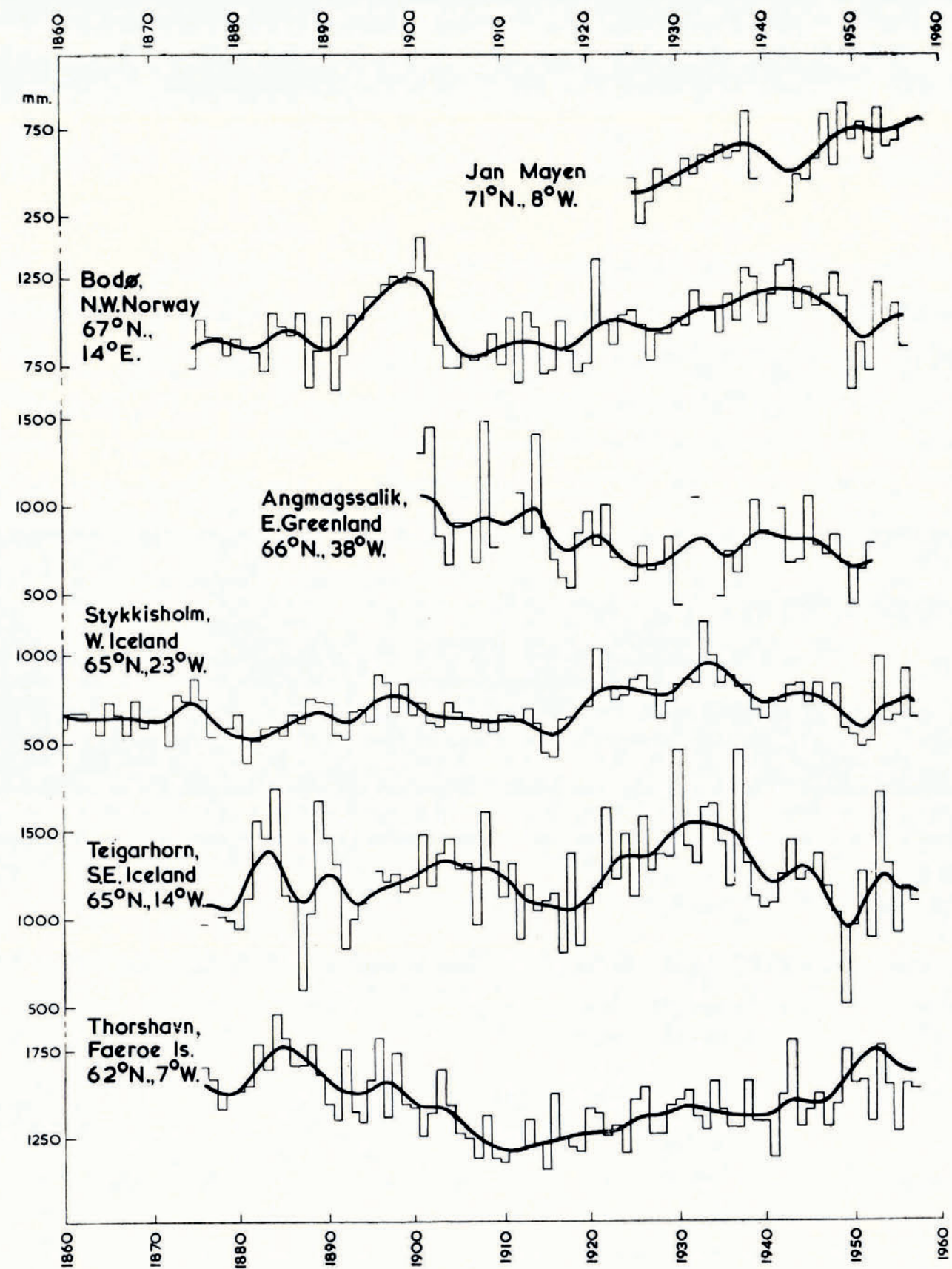

Fig. 3. Annual precipitation totals. Bold curves, smoothed. Narrow line indicates yearly values. Years with missing months have been omitted

It seems possible to explain many of the features of these precipitation trends by reference to changes in prevailing depression tracks and wind directions indicated by the circulation studies of Lamb and Johnson (1959, I96r), Petterssen (1949) and others. The period of 
generally low rainfall in the region around I9 I0-20 was a time when the Atlantic cyclonic activity tended to keep away to the south-west of Iceland or near south Greenland, as indicated by the exceptional case of Angmagssalik where this meant more onshore winds and precipitation was correspondingly high. Precipitation increased after 1920 at all the other places examined, as cyclonic activity became more vigorous and spread farther north, up to the I930's or early 1940's. At its climax this trend probably introduced a tendency for some decrease of rainfall at the Faeroe Islands in the southernmost part of the region examined, because of less frequent depressions in their vicinity. The particularly sharp decline of precipitation in eastern Iceland after the mid-I930's may partly be due to lee effect, increasingly frequent westerly winds accompanying depressions centred well to the north. Precipitation at Spitsbergen certainly increased up to I940, though some dry years in the early I930's produced a marked oscillation. It seems probable that these variations corresponded fairly well with the frequency of depressions near Spitsbergen. Since the late 1940's many of these trends have reversed: this too corresponds with a marked new trend of the circulation patterns with the depressions more frequently following southern tracks near the Faeroe Islands and east Iceland.

The continued slight upward trend of precipitation amount at Jan Mayen appears as an enigma in the light of this latest circulation development. At the same time as the depressions have reverted to more southern tracks average atmospheric pressure has risen and northerly wind components have increased in frequency. (Yearly mean pressure values for $195^{1-60}$ were above the $1900-39$ normal by $3.0 \mathrm{mb}$. in central Greenland at lat. $70^{\circ} \mathrm{N}$., long. $40^{\circ} \mathrm{W}$. and by $0.9 \mathrm{mb}$. at Jan Mayen.) One possible explanation of the precipitation is that moisture content in the warm airmass involved in frontal rain- and snowfall has probably continued to increase, as the secular rise of sea temperature has continued east of Iceland and in the eastern part of the Norwegian Sea or no more than levelled off in the very latest years (see, for instance, Roll (r96r) and values for the Norwegian weather ship station M (lat. $66^{\circ}$ N., long. $2^{\circ}$ E.)).

Precipitation is fairly well distributed around the year at all the places here represented but with a distinct maximum in the six months September to February-at Jan Mayen these months account for about two-thirds of the annual total. Variations of the Jan Mayen glaciers over the whole period of observation since I 8 I 7 show some inverse correspondence with the pressure level at Trondheim, particularly in December, January and February, which suggests that prevalence of low pressure over the Norwegian Sea and concomitant frequency of cyclonic snowfall has perhaps been the most important control of these glaciers over all this time. This is not an unambiguous index, however, since periods of unusually high pressure at Trondheim must usually be accompanied by an excess of southerly winds over the Norwegian Sea and warm air advection at Jan Mayen. Figure 4 illustrates the trend of pressure at Trondheim in the months named in this paragraph.

\section{Conditions at Spitsbergen}

For comparison, Figure 5 shows the changes of prevailing temperature in summer and winter at Isfjord Radio Station, Vestspitsbergen (lat. $78^{\circ} 04^{\prime}$ N., long. $13^{\circ} 3^{8^{\prime}}$ E.) by five-year mean departures from the I $912-30$ period average. This was the method of presenting a homogeneous observation series adopted by Hesselberg and Johannessen (1958), and their figures have been brought up to date using data broadcast under World Meteorological Organization arrangements in monthly CLIMAT messages and Monthly Climatic Data for the World (U.S. Weather Bureau).

The slight reversal of the annual temperature trend since the I930's so far affects only winter and spring; the most recent summers and autumns have ranked with or near the warmest. Nevertheless, the former general retreat of Spitsbergen glaciers is believed to 
have greatly slowed down in the last few years, and one or two glaciers have shown signs of advance since I957 (Kosiba, I960). It does not seem likely that the colder winters and springs would produce a reversal of the glacier regime.
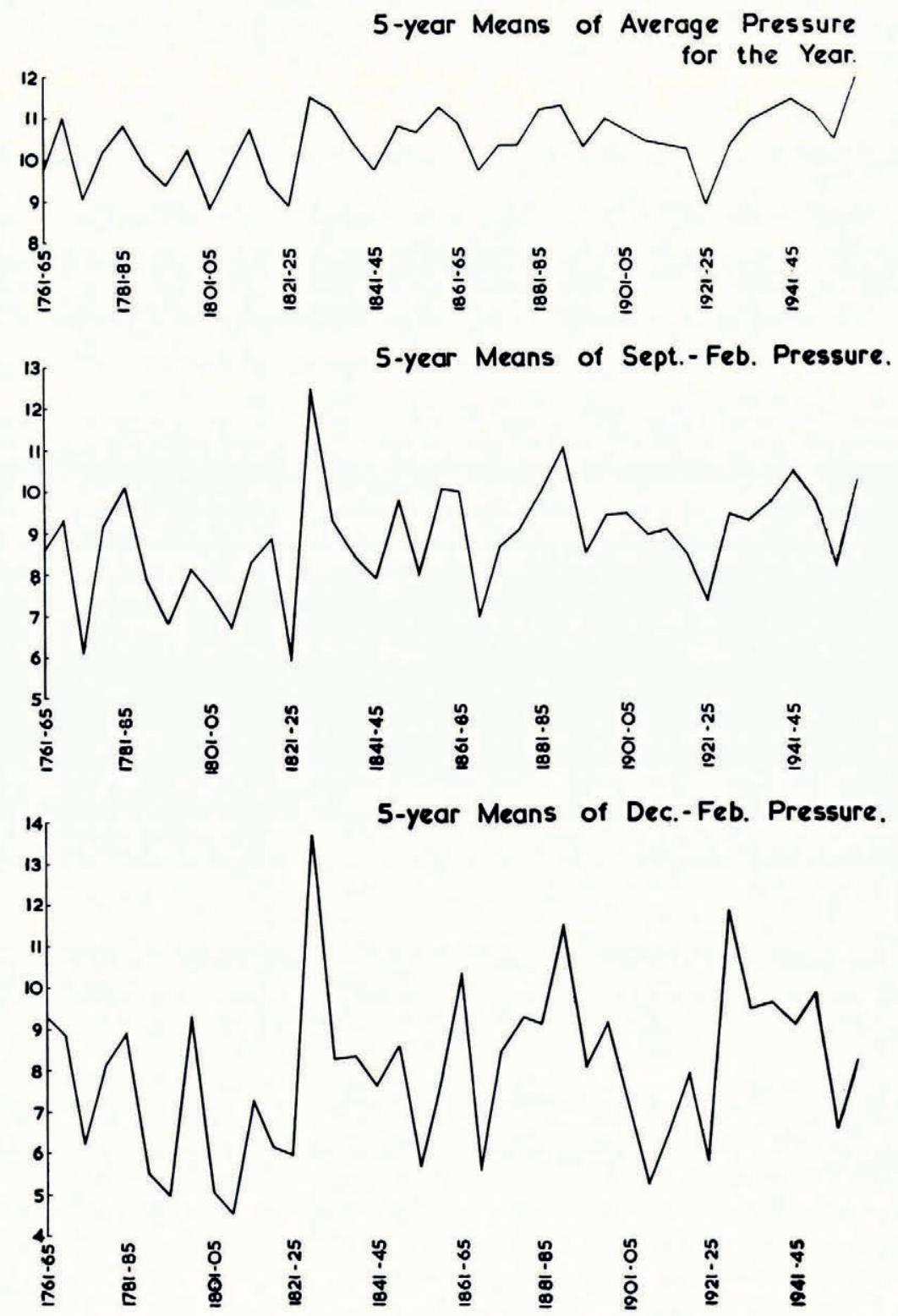

Fig. 4. Mean sea-level pressure at Trondheim (lat. $63 \cdot 4^{\circ}$ N., long. $10 \cdot 5^{\circ}$ E.)

There are no indications of recent increase of precipitation at Spitsbergen, though the matter cannot be studied satisfactorily because of changes of observing station in 1930 and I 934 and several years' break in the series in the war. The figures for the observing stations 
near the west coast suggest a material reduction of the annual precipitation totals since the peak amounts measured in the late I920's and I936-40. The average yearly totals measured at the Grønfjord site (lat. $78^{\circ} 2 \mathrm{I}^{\prime} \mathrm{N}$., long. $14^{\circ} \mathrm{I} 4^{\prime}$ E.) in $192 \mathrm{I}-29$ were 27 per cent, in $1926-29$ 49 per cent, above the 1912-20 figure; and at the present site the average yearly totals measured in $193^{6}-40$ were $4^{8}$ per cent above the $1947^{-} 5^{8}$ figure. However, on a rugged island with mountains up to $\mathrm{I}, 400 \mathrm{~m}$. high and where winds with easterly components prevail, the trend of precipitation measured at just one part of the west coast is clearly an insufficient guide to variations in the moisture supply to the glaciers.
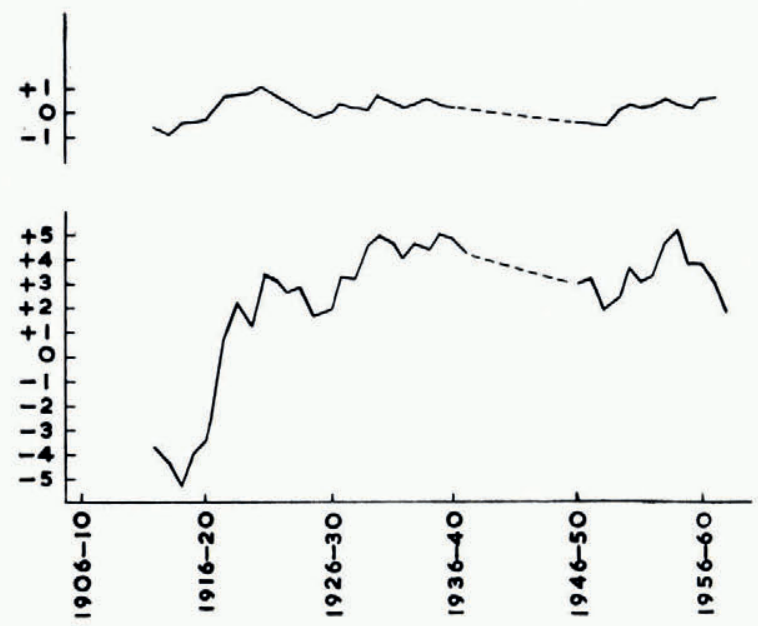

Fig. 5. Spitsbergen (Isfjord Radio): departures of average temperature for the summer (June, July, August) and winter (December, January, February) from the average for $1912-30$ (5-yr. mean departures)

Evidently the position at Spitsbergen cannot be resolved as yet. The relevant precipitation trend over the mountains may in reality be not so unlike that at Jan Mayen. It is established that the percentage changes of equivalent rainfall on the west coast since $1912-20$ have been of as striking magnitude as at Jan Mayen, though in the case of Spitsbergen changes in frequency of east winds, and hence of the orographic effect, must play a significant part as well as changes of frequency of depressions in the vicinity.

Changes of prevailing wind direction at the Isfjord Radio station, Spitsbergen do indicate fewer cyclones in the highest latitudes since 1935-40. Comparisons are complicated by the adoption of thirty-degree sectors instead of octants for wind-direction statistics since r949; this can, however, be overcome by quoting only ratios of the frequencies of easterly and westerly or northerly and southerly components as is done in Table II. The figures are for the whole year.

Table II. Winds at Isfjord Radio, Spitsbergen

\begin{tabular}{|c|c|c|c|}
\hline Frequency & $\begin{array}{l}\text { Ratio } \\
\text { E/W }\end{array}$ & $\begin{array}{l}\text { Ratio } \\
\text { N/S }\end{array}$ & $\begin{array}{c}\text { Number of } \\
\text { calms }\end{array}$ \\
\hline $1935-40$ & $2 \cdot 3$ & $1 \cdot 7$ & $20 \cdot 3$ \\
\hline $1947-58$ & $3 \cdot \mathrm{I}$ & $2 \cdot 1$ & $34 \cdot 7$ \\
\hline
\end{tabular}

Clearly the increased frequency of easterly winds since the war implies that the sharp decrease of precipitation on the west coast may not have been accompanied by such a great decrease, or even by any decrease at all, in the precipitation on the east side or over the Spitsbergen mountains. 
These are points that might usefully be investigated by glaciological techniques on the ice in the interior of the island of Vestspitsbergen.

\section{Periodicities in the Pregipitation over the Jan Mayen Region}

The precipitation changes were examined for possible traces of periodicities. This is an aspect of meteorological variations which has seldom proved rewarding. Among the reasons are, first, that few of the agencies responsible, and perhaps only those changes in the energy supply which are produced by the regular astronomical motions of Earth and Sun, etc., really approximate to the form of a sine wave; secondly, that such periodicities as have been found seldom account for more than a small fraction of the variations occurring. For the latter reason, the discovery of a periodic variation does not usually solve the problem of forecasting. Where so much obscurity exists, there is a prospect that discoveries of further suggested periodicities will not be made much use of. Periodogram analysis of the curves here presented did in fact suggest several periodicities with indications of regular phase differences between different parts of the region, but in no case was it possible to establish the validity of the periodicity beyond argument. Most interest attaches to indications of a $2 \cdot 2$-year period in the precipitation at Jan Mayen, which is possibly statistically significant, though the main grounds for believing in the probable existence of a physical cause are to be found in indications of an apparent periodicity of just this length ( 26 months) in several sorts of atmospheric circulation phenomena in widely separated parts of the world (Berlage, r957; Ebdon, 196r ; Veryard and Ebdon, i96r).

\section{Conclusion}

From these investigations it is clear that, whilst the Jan Mayen glaciers are sensitive to both temperature and precipitation changes, the latter have probably been the more important over the last i 50 years. There appears to have been an upward secula: trend of temperature and precipitation associated with increased cyclonic activity in the northern parts of the Norwegian Sea, especially when the late I920's and I930's are compared with any other time since at least $185^{\circ}-70$. However, at Jan Mayen precipitation has continued to increase since the I930's for reasons which cannot be completely established but are probably related to higher sea temperatures than formerly to the east and south. The percentage changes of precipitation since about 1920 are very great, and the present advance of the glaciers on Jan Mayen is probably an exceptionally near approach to an ideal case of a reversal entirely attributable to the precipitation trend.

\section{Acknowledgement}

The first two authors who were on the staff of the Meteorological Office at the time the work reported here was done wish to thank the Director-General of the Meteorological Office for facilities used and for permission to publish this article.

\section{MS. received 15 June 1962}

\section{REFERENCES}

Berlage, H. P. 1957. Fluctuations of the general atmospheric circulation of more than one year, their nature and prognostic value. Mededeelingen en Verhandelingen, Koninklijk Nederlandsch Meteorologisch Instituut, No. 69, p. I-I 5 I.

Ebdon, R. A. I96r. Some notes on the stratospheric winds at Canton Island and Christmas Island. Quarterly Journal of the Royal Meteorological Society, Vol. 87, No. 373, p. 322-31.

Hesselberg, T., and Johannessen, T. W. 1958. The recent variations of climate at the Norwegian Arctic stations. (In Sutcliffe, R. C., ed. Polar atmosphere symposium. Part I. Meteorology section. London, Pergamon Press, p. I 8-29.)

Jennings, J. N. 1948. Glacier retreat in Jan Mayen. Journal of Glaciology, Vol. 1, No. 4, p. 167-71, 178-81. 
Kosiba, A. 1960. Some of [the] results of glaciological investigations in SW-Spitsbergen carried out during the Polish I.G.Y. Spitsbergen expeditions in 1957, 1958 and 1959. Nauka o Ziemi I, Uniwersytet Wroctawski im. Bolestawa Bieruta Zeszyty. Naukowe Nauki Przyrodnicze, Ser. B, No. 4, 29 p.

Lamb, H. H. 1957. On the frequency of gales in the Arctic and Antarctic. Geographical Journal, Vol. 123, Pt. 3, p. $287-97$.

Lamb, H. H., and Johnson, A. I. 1959. Climatic variation and observed changes in the general circulation. Parts I and II (January). Geografiska Annaler, Årg. 4I, Ht. 2-3, p. 94-1 34 .

Lamb, H. H., and Johnson, A. I. I961. Climatic variation and observed changes in the general circulation. Part III (July). Geografiska Annaler, Årg. 43, Ht. 3-4, p. 363-40o.

Mitchell, J. M. I961. Recent secular changes of global temperature. (In "Solar variations, climatic change and related geophysical problems". Annals of the New York Academy of Sciences, Vol. 95, Art. 1, p. 235-50.)

Mitchell, J. M. In press. On the world-wide pattern of secular temperature change. Proceedings of the UNESCOWMO Rome symposium on climatic change and the arid lands, 2-8 October 196I.

Petterssen, S. 1949 . Changes in the general circulation associated with the recent climatic fluctuation. Geografiska Annaler, Arg. 31, Ht. I-2, p. $212-21$.

Roll, H. U. 1961. Die Luft- und Wassertemperaturen auf den Fischfangplätzen bei Island. Deutscher Wetterdienst (Seevetteramt). Einzelveröffentlichungen, Nr. 31 . Veryard, R. G., and Ebdon, R. A. 1961. Fluctuations in tropical stratospheric winds. Meteorological Magazine,
Vol. 9o, No. 1066, p. 125-43. 